\title{
鼻副鼻腔乳頭腫10症例の検討
}

\author{
戸田均・西村 忠郎・高須 昭彦・内藤 雅夫 \\ 堀部 幸元・戸田 富貴・岩田 重信
}

\section{Ten Cases of Inverted Papilloma in the Nasal and Paranasal Cavities}

\author{
Hitoshi Toda, Tadao Nishimura, Akihiko Takasu, Masao Naitoh, \\ Yukimoto Horibe, Fuki Toda and Shigenobu Iwata \\ (Fujita-Gakuen University)
}

Inverted papilloma in the nasal and paranasal cavities is a rare disease and is also very difficult to distinguish from other nasal tumors. Generally speaking it seems to be characterized by multiple recurrences and tends to become malignant.

Clinical and pathological studies of inverted papilloma growing in the nasal cavity and paranasal sinuses were performed in 10 patients treated in the last 6 years in our clinic.

The results were as follows.

They consisted of 8 males and 2 females, and the mean age was 50.2 years ranging from 32 to 79 . The chief complaint was mainly nasal obstruction caused by the papillomatous mass. Inverted papillomas in 3 patients were pathologically associated with a slight degree of mitosis, an irregular from of nuclei and also hyperkeratosis. For treatment, patients performed radical operation and 3 had additional irradiation of 40Gy. Recurrence of this disease has been recognized in 2 cases up to the present.

はじめに

鼻副鼻腔乳頭腫は, 比較的桸な㾏性腫瘍とされるが, その組織破壊性, 翡再発傾向, 悪性化, 組

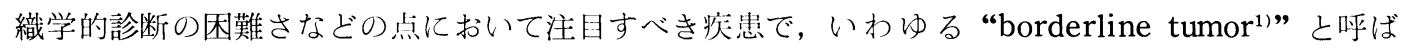
れる. 今回, 我々は, 昭和 52 年 4 月より昭和 57 年 6 月の間に, 10 例の鼻・副鼻腔乳頭腫を経験した ので報告する.

症例

症例 1

$<$ 患者 $>32$ 才, 男性.

$<$ 初診>昭和 52 年 4 月 5 日.
<主訴>右鼻閉.

<家族歴・既往歴〉特記すべきととなし.

<現病歴>約 1 年前より右鼻閉, 鼻漏を認 
め, 6 ケ月前より, 前頭部痛, 後鼻漏を自覚.

4 月13日，近医受搒，右鼻茸を指摘され，当科 受診.

<局所々見>右中鼻道に乳頭腫を疑わせる腫 瘍が充満。

$<\mathrm{X}$ 線所見 $>$ 右上顎洞・穊骨洞に高度陰影を 認めた。左上顎洞・篩骨洞にも軽度陰影を認め たが，骨欠損を疑わせる所見は認めなかった。

<病理組織所見>上皮の乳頭状増殖，掞よび metaplasia を認め, 一部には浮腫性ポリープ の所見も混在していた。

＜治療＞局麻下に Caldwell-Luc 氏手術に準 じ，腫瘍を摘出した，中鼻道に充満した腫瘍は 自然口を通じ，右上顎洞内側壁を占める腫瘍に 連続していた，骨欠損は認めなかった。篩骨洞 粘膜は, 浮腫状の肥厚を認るのみであった。術 後, 放射線照射 $(40 \mathrm{~Gy})$ （リニアック）を追 加した，現在に致るまで，腫瘍の再発を認めな い.

症例 2

<患者〉 50才, 女性.

$<$ 初診>昭和 52 年 5 月 28 日.

$<$ 主訴 >右鼻閉.

＜既往歷・家族歴＞特記すべきことなし.

<現病歴>約 1 年前より右鼻閉，および鼻漏 を自覚. 6 ケ月前より右完全鼻閉を認めた。昭 和52年 5 月 27 日, 近医にて, 右鼻腔腫瘍を指摘 され，当科受診.

<局所々見>右鼻腔は, 乳頭腫を疑わせる腫 瘍が，充満していた。

$<\mathrm{X}$ 線所見 $>$ 右上顎洞 - 篩骨洞に中等度陰影 を認めるも, 骨欠損は認めず, さらに, 左上顎 洞・篩骨洞にも陰影は，認めなかった。

<病理組織所見>鼻腔内腫瘍の生検組織 で は，ポリープを形成している部は大部分，上皮 の乳頭状增殖を認めた。 上顎洞粘膜には，上皮 の肥厚を伴うポリープを認めるのみであった.

〈治療〉乳頭腫の病理診断の下に, CaldwellLuc 氏手術に準じ，腫瘍を摘出した，手術所見 より, 鼻腔内腫煬は, 自然口付近から発生した
あのと思われ，上顎洞，および，穊骨洞には， 粘膜の浮腫性変化を認めるのみであった。骨欠 損はなく，腫湯は全摘出出来たと考えられた。 現在, 再発の徵候はない。

症例 3

<患者 > 53才, 男性。

$<$ 初診 $>$ 昭和 54 年 3 月 2 日.

$<$ 主訴>右鼻閉・鼻出血.

＜既往歴・家族歴＞特記すべきことなし.

$<$ 現病歴 $>$ 約 8 年前より鼻閉, 鼻漏を認め, 近医受診. 右鼻茸を指摘され，鼻茸摘出術を受 けた。 5 年前, 右 Caldwell-Luc 氏手術を受け た。また， 1 年前より鼻出血を繰り返してい た。 1 週間前，近医受診し，右鼻腔腫瘍の疑い にて，当科を紹介された。

<局所々見>右中鼻道に腫瘍が充満し, 腫瘍 の下方には，易出血性の部位を認めた。中咽頭 には，血性後鼻漏を認めた。

$<\mathrm{X}$ 線所見 $>$ 右上顎洞，および，右篩骨洞に は，経手術による㓌影を認め，さらに右眼窩下 壁には骨欠損を疑わせる所見があり，左上顎洞

・篩骨洞にも軽度陰影を認めた。

<病理組織所見>腫瘍は乳頭状に増殖した上 皮よりなり，間質に向い増生するが，基底膜は 保たれ，特に悪性像は認めなかった。

〈治療>初診時, 右鼻腔からの乳頭腫の組織 診断を得たため，鼻・副鼻腔根本手術を勧める も，本人が希望しなかった。そてで鼻内より， 乳頭腫摘出術を 3 回施行したが，現在，腫瘍の 再発傾向を認めている.

症例 4

<患者〉—69才, 女性.

$<$ 初搒>昭和 54 年 5 月 28 日.

$<$ 主訴 $>$ 左鼻閉, 鼻出血.

〈既往歴・家族歴＞特記すべきことなし.

<現病歴> 2 ケ月程前より左鼻閉, 鼻出血を 認め, 近医を受診. 左上顎腫煌を疑い, 当科紹 介された。

<局所々見>左中鼻道に, 暗赤褐色の腫湯を 認めた。 
$<\mathrm{X}$ 線所見 $>$ 左上顎洞のみに，高度陰影を認 め, 左眼窩底には，骨欠損を疑わせる除影を認 めた。

<病理組織所見>左中鼻道からの術前の病理 組織検査では，扁平上皮の間質への過形成を示 し,さらに移行上皮の増生を認め, 乳頭腫之診 断された。 また，手術時採取した，左上顎洞・ 篩骨洞粘膜は, ポリープ様を呈し, 粘膜下の浮 腫があり, 副鼻腔炎の所見のみで, 乳頭腫の所 見は認めなかった。

〈治療〉乳頭腫との組織診断により, Caldwell-Luc 氏手術に準じ，腫瘍を摘出した。.上 顎洞・篩骨洞ともに, 高度浮腫状を呈す粘膜を 認めるのみで，腫瘍，および骨火損は認めなか った，現在，再発傾向を認めない。

症例 5
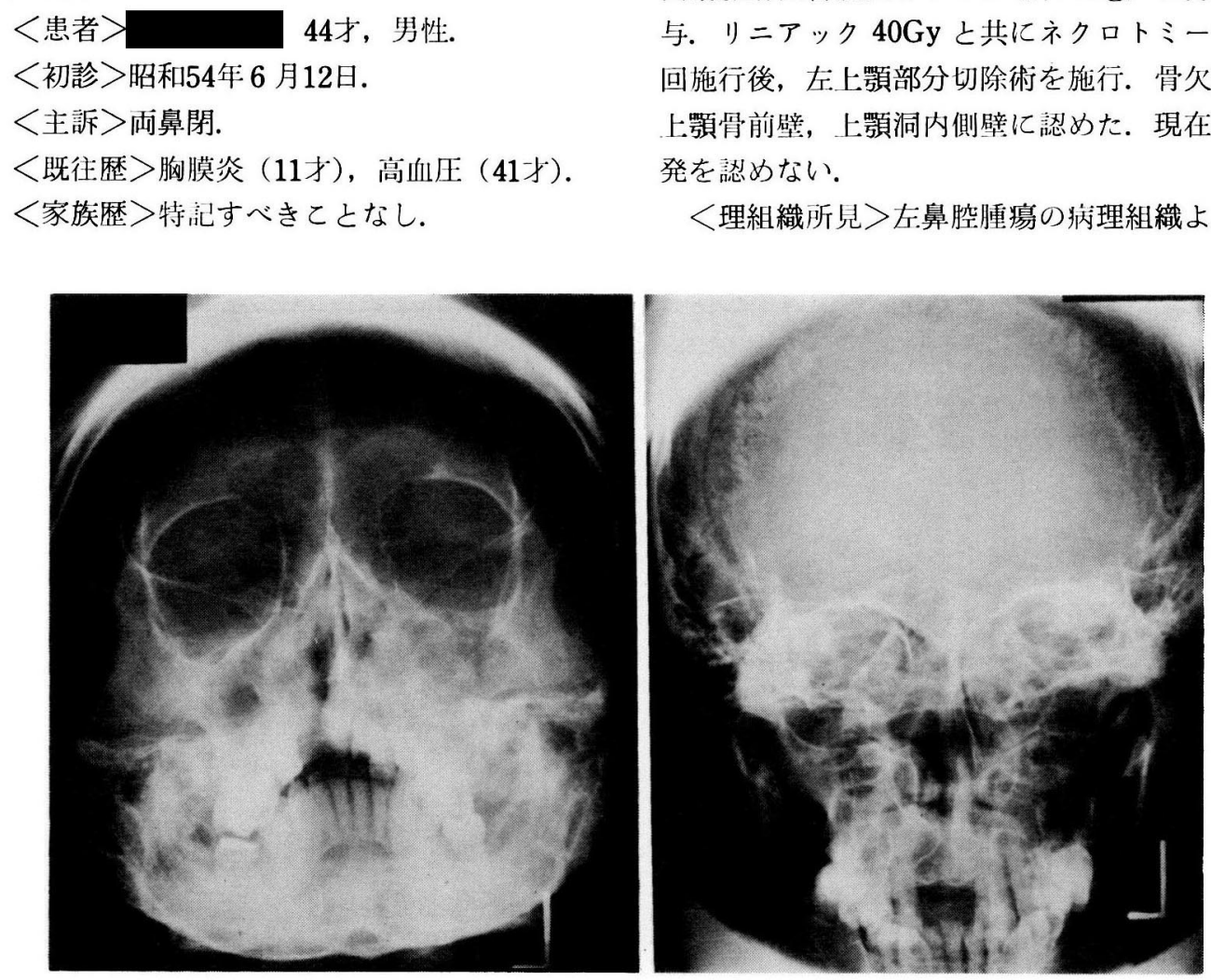

写真 I 症例 5 の後頭鼻部撮影（左）と後頭前頭撮影（右）. 術前，左眼窩底および左鼻腔側壁に骨欠損を疑わせる所見を認め， 左上顎覀性腫湯を疑った。
<垷病歴>約 2 年前より，両側の鼻閉，およ び, 年 $2 \sim 3$ 回の鼻出血を認め, 54 年 5 月 8 日，近医受診。6月 5 日試験開洞を施行し, 病 理組織検査にて乳頭腫の一部に癌を疑う所見を 認めるとの診断を得たので，当科へ紹介され た.

<局所々見>初搒時, 左鼻腔内は, 生検後の 為, 腫瘍之ともに, 痂皮を認め, 易出血性であ った，中咽頭にも，上咽頭からの腫瘍の下垂を 認めた。頸部リンパ節は触知しなかった。

$<\mathrm{X}$ 線所見 $>$ 左上顎洞・笁骨洞に, 高度陰影 を認め，さらに左鼻腔側壁と左眼浻底に骨欠損 様陰影を涊めた。右上顎洞・穊骨洞にむ，中等 度陰影を垫めた（写真 1 ）。

<治療>57年 6 月 13 日, 浅側頭動脈上り左顔 面動脈動注管設置し 5-Fu（計45mg）を持続投 与. リニアック $40 \mathrm{~Gy}$ と共にネクロトミーを 2 回施行後, 左上顎部分切除術を施行．骨欠損を 上顎骨前壁，上顎洞内側壁に認めた，現在，再 発を認めない.

<理組織所見 $>$ 左鼻腔腫瘍の病理組織より， 


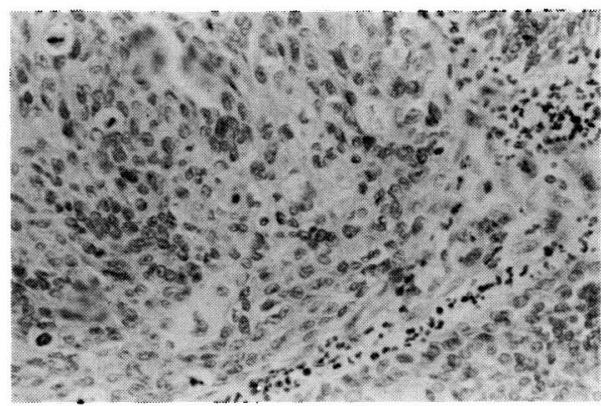

写真 2 症例(5)の左㝴腔の病理組織像 $(\times 400)$ inverted papilloma の中に異形細胞, 核分裂像および細胞配列の乱れを認め, Carcinoma in situ と唁断された.

乳頭腫之上皮内癌の混在を認めた（写真 2 ). さらに左下甲介後端, および，上顎洞内では， 内側壁, 自然口付近, 眼窩下壁に存在していた 腫瘍組織所見は，円柱上皮が不規則に乳頭状に 突出し，ところどころに，扁平上皮化生を認め た。浸潤性增生や, 異形成は認められなかった。 症例 6

\section{<患者〉 46才, 男性.}

$<$ 初診〉昭和 54 年 9 月 28 日.

$<$ 主訴>両鼻閉.

〈既往歴・家族歴＞特記すべきととなし.

〈現病歴>約10个月前より両鼻閉があり, 次 第に増強してきたため, 当科受誩.

<局所々見>右中鼻道には，浮腫性変化の強 いポリープが充渾し，ポリープ基部には発赤を 認め, 易出血性であった。

$<\mathrm{X}$ 線所見 $>$ 右上顎洞に, 高度陰影, 右穊骨 洞に軽度除影を認めるが，骨欠損像はなかっ た，左上顎洞・穊骨洞には軽度㓌影を認めるの みであった。

<病理組織所見>右鼻腔腫焬の組織像は扁平 上皮の間質への増殖, 過形成を認めるが, 異形 成，浸潤傾向は認めなかった（写真 3 ).

〈治療〉 Caldwell-Luc 氏手術に準じ腫瘍を 摘出した。腫瘍は，鼻腔のみに存在し，自然口 付近，および，上顎洞・穊骨洞粘膜は浮腫性変 化を認めるのみであった。骨欠損は認めなかっ

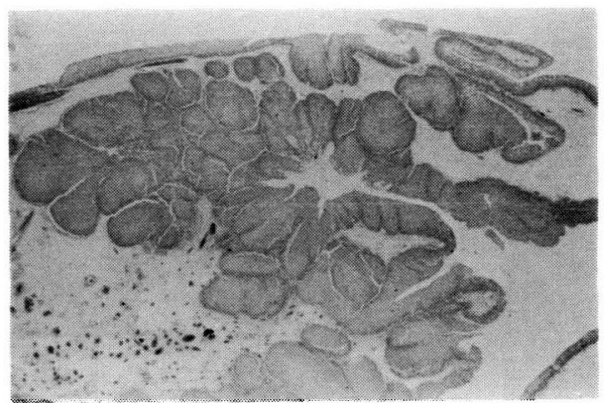

写真 3 症例(6)の右鼻腔の病理組織像 $(\times 100)$ 重層扁平上皮が，問質に向ってクロバー 状に增殖するも，浸潤傾向，異形細胞は 認められなかった. inverted papilloma と誩断された。

た.

症例 7

<患者〉正 79才, 男性.

$<$ 初診>昭和 55 年 1 月 9 日.

<主訴>右煩部腫脹.

〈家族歴〉特記すべきことなし．

〈既往歴〉約11年前，右上顎癌にて右上顎全 摘術，および放射線治療を受けている．初診 時, 気管支拡張症, および肺炎にて内科に入院 し, 加療中であった。

<現病歴>内科に入院中，右煩部の膿煬を指 摘され当科を受診.

〈全身所見>肺炎のため, 全身状態は不良で あった。

く局所々見および経過＞右煩部に膿煬を認め た.これは11年前の上額全摘術後の右上顎骨に 穿孔があり，この穿孔より㾇孔を形成し，右煩 部に膿煬を形成したすのと推定された。上顎骨 の穿孔部の経過観察中, 穿孔部のやや下方に肉 芽状腫瘤を認めたため, この部より, 病理試験 切片を採取した。その結果, 乳頭腫との組織診 断を得た。そこで, さらに, 増殖傾向の強い腫 瘍部を, 再三, 検査した結果, 扁平上皮癌との 診断を得た（写真 4 ）. 全身状態不良にて, 腫 鹪に対する治療は不可能であったが, 頸部, お よび遠隔転移は認めないまま 1 年 4 ケ月後, 肺 炎にて死亡した。 


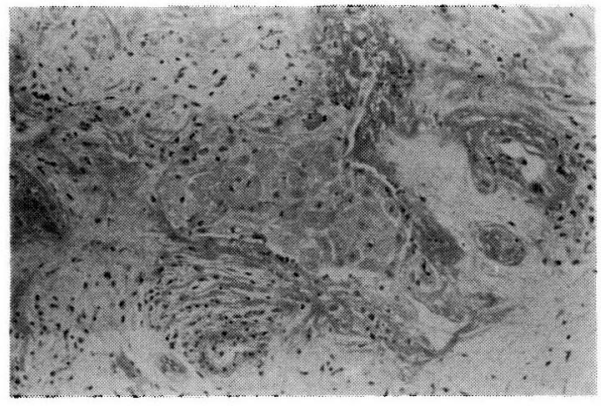

写真 4 右上頢肉芽部の病理組織 $(\times 400)$

異形成を示寸重凰扁平上皮をみる．周囲 組織に変性を認めた。扁平上皮癌と診断 された。

く病理組織所見〉前述の経過のところに此 したごとくである.

症例 8

<患者〉 37才, 男性.

$<$ 初診>昭和 55 年 6 月 14 日.

<主挀〉右鼻出血.

〈既往歴〉小児期にアレルギー性鼻炎.

〈家族歴〉特記すべきことなし.

<現病歴>約 2 年前より鼻出血を繰り返す.

3 ケ月前より, 頭痛, 右煩部痛が出現し, 当科 を受診.

＜局所々見＞鼻腔内は右中甲介の浮腫性腫脹 を認める他，両側下甲介の腫脹を，認めるのみ であった。

$<\mathrm{X}$ 線所見 $>$ 右上顎洞にのみ中等度陰影を認 め,さらに，右上顎洞内侧に高度㓌影を認め た.

<病理組織所見〉手術時の右上頢洞粘膜は扁 平上皮の間質に向う乳頭状増殖を認め，上皮下 は浮腫状で，好中球の浸潤を多数認めた。悪性 所見は認めなかった。

<治療>右片側性副鼻腔炎之診断し, Caldwell-Luc 氏手術施行した。 上顎洞・篩骨洞粘 膜は，共に浮腫性変化を認めるのみで，明らか な，腫瘍所見はなかった。病理検査にて上䝷洞 粘膜に乳頭腫を認めた。現在も経過観察中であ るが, 再発傾向を認めない.
症例 9

<患者 $>$ 51才，男性.

$<$ 初診>昭和56年 1 月 10 日.

<主訴 $>$ 左鼻閉.

〈既往歴〉脳硬寒, 高血厈, 腎不全にて, 入 院し加療中.

〈家族歴〉特記すべきととなし.

$<$ 現病歴 $>4$ 年程前より, 左鼻閉が出現する も放置していた．脳硬塞後遺症，高血圧症，腎 不全にて, 内科に入院加療中, 左外鼻孔より, 腫煬の突出を認め，当科を紹介された。

<局所々自>左外鼻孔より淡紅色，表面が力 リフラワー状の腫瘍の突出を認めさらに，左外 鼻の変形, 流涙を認めた。

$<\mathrm{X}$ 線所見 $>$ 左鼻腔内に腫演の充満を思わせ る院影を認めた。左上顎洞は中等度，左篩骨洞 は高度の陰影を認め，さらに，左鼻腔側壁に骨 欠損を疑水せる所見を認めた（写真 5 ).

<病理組織所見 $>$ 左鼻腔 -上顎洞腫瘍，共 に，扁平上皮の過形成，および，間質内への乳 頭状突出を認めた。

〈治療＞高血压症，腎不全の改善を待ち， Caldwell-Luc 氏手術に準じ，腫瘍を摘出した。 膜様部付近，および鼻中隔に骨欠損を認め，上 顎润内は膜様部に腫瘍を認めた。術後,一過性 に, 高血圧, 䴛不全の増悪傾向示すむ, 術後経 過良好で, 腫湯の再発傾向を認めていない.

症例 10

<患者 > 41才, 男性.

$<$ 初診>昭和 57 年 6 月 26 日.

<主訴>右鼻閉, 鼻出血.

＜既往歴〉幼小時にアレルギー性鼻炎.

〈家族歴＞特記すべきととなし.

<現病歴>昭和 50 年, 近医にて右鼻苜摘出術 受けている．同53年右 Caldwell-Luc 氏手術を 受けた。昭和 55 年より，同57年にかけ 4 度の右 鼻咠摘出術を受け, 組織学的検查にて, 乳頭腫 との診断を得たので, 当科紹介される.

<局所々見>右鼻腔内に，腫瘍が充満，後鼻 鏡検査にて腫瘍による右後鼻孔の閉塞を認め 

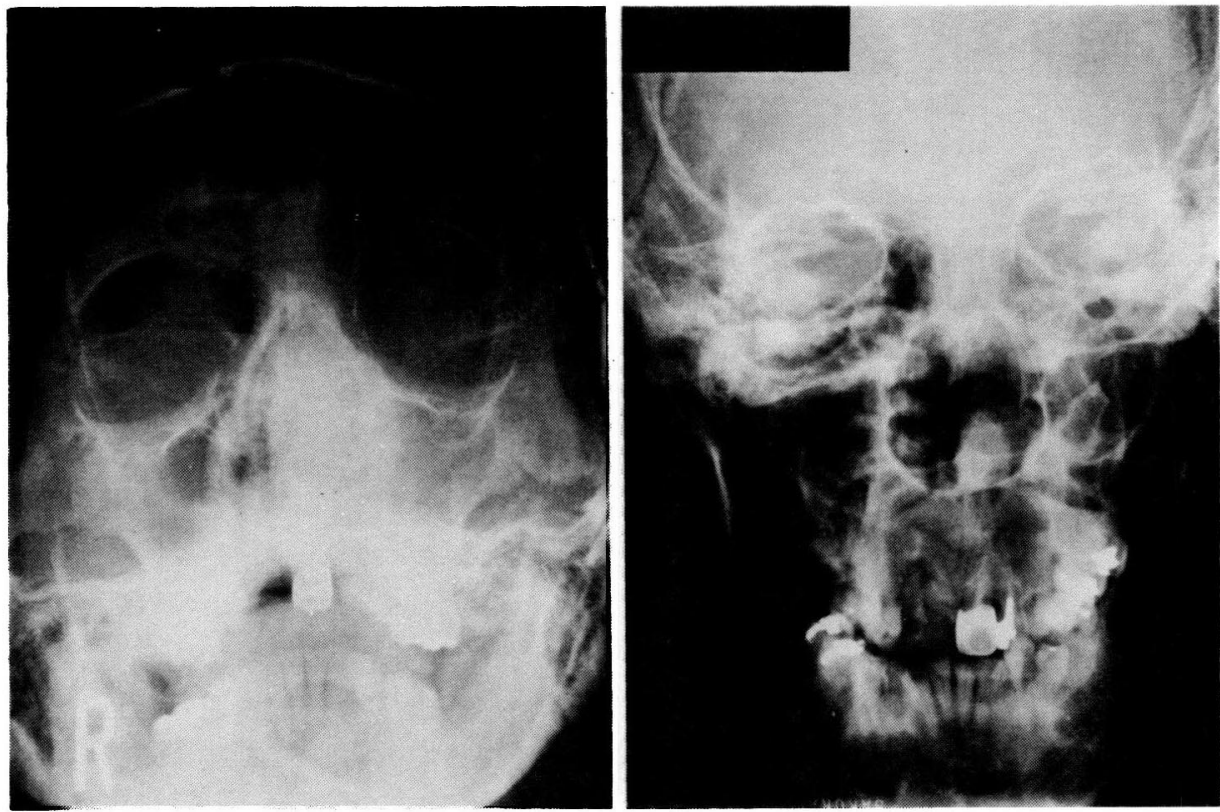

写真 5 症例 9)の後頭部撮影（左）および後頭前頭撮影（右）

左鼻腔および左篩骨洞に高度陰影を㤠め左鼻腔側壁の骨破壊が疑われた。

た。頸部リンパ節は触知しなかった。

$<\mathrm{X}$ 線所見 $>$ 右上顎洞に，高度㓌影を認め， さらに右眼窩下壁に骨久損を疑わせる所見を認 めた。CTにおける所見では，右上顎洞および 鼻腔内に，高度の㓌影を認めた（写真 6 ).

<病理組織所見〉右鼻腔腫瑒は，扁平上皮が 乳頭状に増殖しており上皮内に異形細胞在認め た.

〈治療＞局麻下に Caldwell-Luc 氏手術に䧱: じ，腫瘍を摘出した。 Low grade malignancy との組織診断を得たので，術後照射施行(40 Gy). 照射後, Denker 氏手術に準じ，ネクロ トミ一施行した．現在まで再発傾向は，認めら れていない.
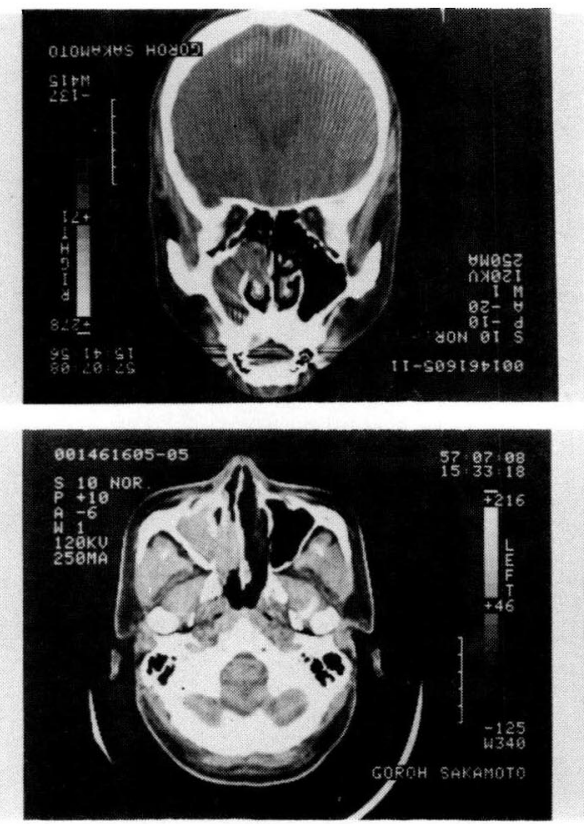

写真 6 症例10の前額C T （上）および軸位（下） 右上䞄洞および鼻腔内に高度の陰影を琵 めた。 


\section{総括ならびに考按}

鼻・副鼻腔の乳頭腫に関する報告は1855年, Billroth が，最初におてなったとされている。 本邦においては，1908年大野の報告以来，幾多 の報告があるが，1969年斎藤1) らは本邦におけ る鼻・副鼻腔乳頭腫 106 例の統計的観察をして いる.

我々は最近 6 年間に10例の鼻・副鼻腔乳頭腫 を経験したので，ここに報告する次第である. 10症例の病像については表 1 に一括し示した. すなわち，年令分布は32才から79才で，平均年 仓 50.2 才, 男性 8 例, 女性 2 例であり斎藤 ${ }^{1}$, 笹 $\left(^{-2)}\right.$, 北条 ${ }^{3)}$ らの男女比は約 $3: 1$ で，男性 優位の腫瘍との報告にほぼ一致する。

症状としては, 表 2 に示す様に鼻閉 (8 例), 頭痛 ( 5 例), 鼻出血 ( 5 例), 後鼻漏 ( 4 例) の順で, 副鼻腔炎類似の症状を訴えるものが多 く, 煩部痛, 煩部腫脹等, 腫瘍を疑わせるもの は比較的少なかった。しかし, 主訴に限れば 片側性鼻閉, 鼻出血を訴えるむのが多かった。 高田4) らによれば, (1)片側性鼻閉, (2)洞症状, (3)鼻漏, (4)鼻部疼痛, (5)鼻出血の順に多いとの 報告があるが，自験例では鼻内にも腫瘍の存在 する例が多いためと思われる。

また，初診までの期間は 2 ケ月から 11 年と広 範におよんでいたが, 症例 7 は，11年前に上顎 全摘術を施行された例であった。

既往歴，および初診時，X線写真にて慢性琶 鼻腔炎の既往を推定されるものが 5 例（50\%） にみられた，文献的には，本腫湯の発生頻度は

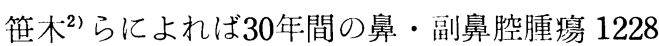
例中 4 例，土井ら ${ }^{5)}$ によれば， 10 年間の副鼻腔 腫煌 245 例中 6 例, 人保ら ${ }^{6)}$ によれば，鼻副鼻 腔良性腫瘍 53 例中 3 例之その頻度は稀（1〜 $2 \%)$ で本腫瘍の発生と慢性副鼻腔炎との因果 関係ありというデーターは得られていない。

初䛦時, 肉眼的, およびX線誩断にて, 乳頭 腫（疑） 5 例，鼻・副鼻腔覀性腫瘍（疑） 3 例, 副鼻腔炎 2 例と自験例では鼻腔に腫煌の存
在するものが多く，比較的診断率が高かった が，松村 ${ }^{7)}$ も言及している様に乳頭腫は，一般 には灰白，淡紅色で弾性を有する腫瘍である が，腫瘍の存在部位により性状が異なる点，ま た，浮腫性変化の強いものは炎症性鼻咠様を呈 する点に注意を要する．本疾患の特徵の一つに 骨破壊性が挙げられるが，自験例では，X線 上，骨欠損像を呈するむのは 5 例（症例 $3 ， 4$, $5 ， 9 ， 10 ）$ 亿認められた。尚，手術時に骨火 損を確認できたのは, 症例 5 , 症例 9 の 2 例で あった。

腫瘍の存在部位は表 $3^{8)}$ に示した。すなわち， 鼻腔 8 例, 上顎洞 7 例, 篩骨洞 1 例之諸家の報 告より副鼻腔，特に上顎洞に存在するむのが多 かった。次に，乳頭腫の易再発性，悪性化傾向 を考察する目的で, 病理組織学的診断の経時的 変化を表 4 に示した。すなわち，全例ともに， inverted papilloma と診断され, 腫㕡摘出後 も, 乳頭腫の再発を繰り返す症例は 1 例で, こ の症例はX線所見にて副鼻腔にも腫瘍の存在を 疑わせる屯，根治術を拒否した症例 3 のみであ る. 他の 6 例は治療後の再発を認めなかった。 残りの 3 例中 1 例は, 再三の組織学的検索によ り乳頭腫より扁平上皮癌に, 移行を示した例 で，11年前に上顎癌にて上顎全摘術を受けてい た. 最後の 2 例は, 乳頭腫と悪性像の混在を認 めた例であるが，そのうちの 1 例は，乳頭腫の 再発を認めたが，他の 1 例は，現在に致るまで 再発を認めていない.

乳頭腫の再発については, Batsakis" らの270 例中 134 例 $(49.6 \%)$. Snyder ${ }^{10)}$ らの 35例中 26 例. 北条3)らの 55例中 6 例（11\%）に再発をみ たとの報告があるが, 自験例では, 何らかの治 療を行い得た 9 例のうち 2 例に再発をみたに過 ぎない，自験例からも，治療の根本は，腫瘍の 完全摘出にあると考えられる. しかし，一方， 渡辺 ${ }^{11}$ は, 文献中には, 完全に摘出された之考 えられる症例にも, 再発をみている症例のある 


\begin{tabular}{|c|c|c|c|c|c|c|c|c|c|c|}
\hline 紧 & 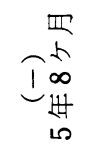 & $\overbrace{\underset{4}{\frac{H}{6}}}^{\frac{\pi}{\hbar}}$ & 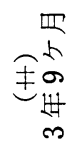 & 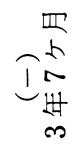 & 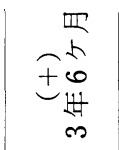 & 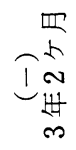 & 宸 & 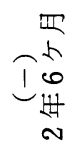 & 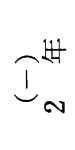 & $\overbrace{0}^{\frac{W}{5}}$ \\
\hline 慗 & 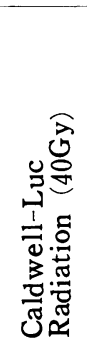 & 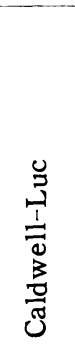 & 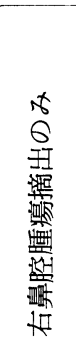 & 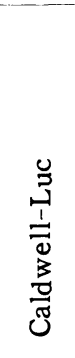 & 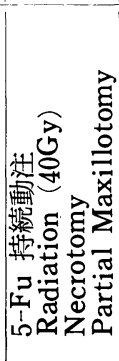 & $\begin{array}{l}0 \\
\vdots \\
1 \\
\overline{0} \\
0 \\
0 \\
0 \\
0 \\
0\end{array}$ & 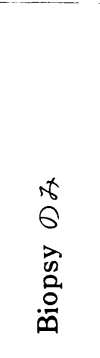 & 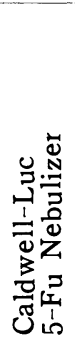 & $\begin{array}{l}0 \\
3 \\
1 \\
\overline{1} \\
0 \\
\frac{3}{0} \\
\frac{0}{\pi}\end{array}$ & 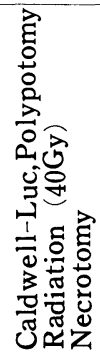 \\
\hline 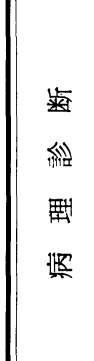 & 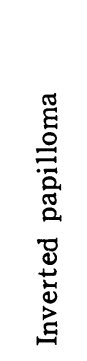 & 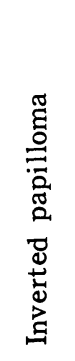 & 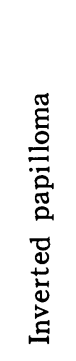 & 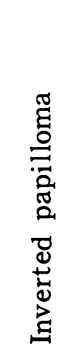 & 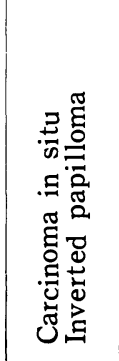 & 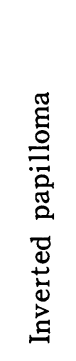 & 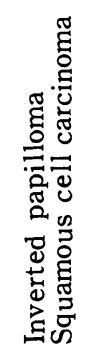 & 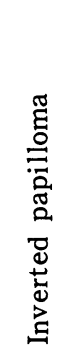 & 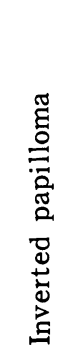 & 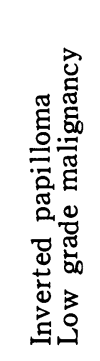 \\
\hline 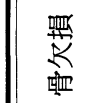 & I & I & 票 & I & I & 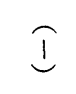 & I & I & I & I \\
\hline 前 & 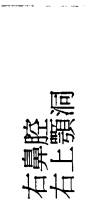 & 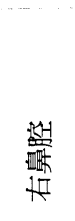 & 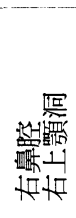 & 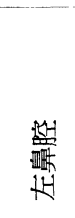 & 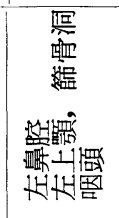 & 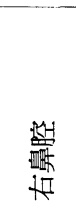 & 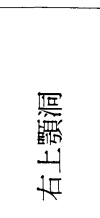 & 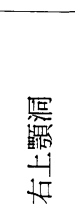 & 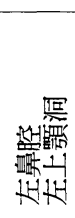 & 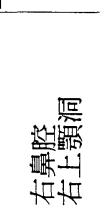 \\
\hline 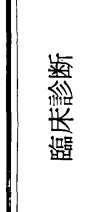 & & 葛 & 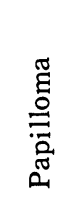 & 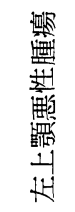 & 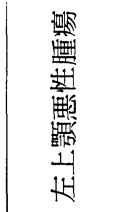 & 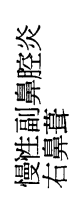 & 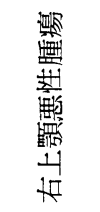 & 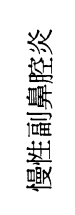 & 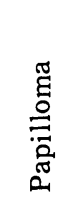 & 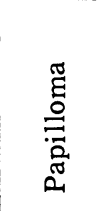 \\
\hline 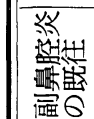 & Ð & I & I & I & 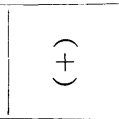 & I & I & I & 王 & I \\
\hline 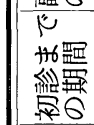 & 这 & $\underset{-14}{-14}$ & $\begin{array}{l}114 \\
\infty\end{array}$ & $\begin{array}{l}\frac{1}{5} \\
\frac{1}{n} \\
\text { N }\end{array}$ & $\underset{\sim}{\mathbb{N}}$ & 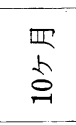 & 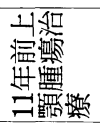 & $\stackrel{\Perp 1}{\stackrel{4}{N}}$ & $\stackrel{14}{\forall}$ & $\underset{\infty}{14}$ \\
\hline $\begin{array}{l}\text { 澁 } \\
H \\
H\end{array}$ & 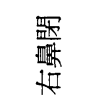 & 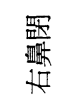 & 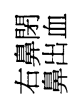 & 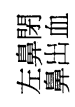 & 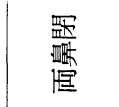 & 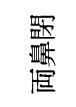 & 1 & 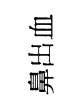 & 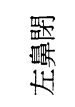 & 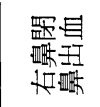 \\
\hline 푼 & to & of & to & of & to & to & to & to & to & to \\
\hline $\begin{array}{l}\text { 仰 } \\
\text { H4 }\end{array}$ & శ్ & 오 & గొ & 8 & $\not{Z}$ & $\mathscr{q}$ & 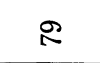 & $\hat{n}$ & [1 & $F$ \\
\hline$\ddot{\Delta}$ & $\Xi$ & $\widehat{\Theta}$ & $\widehat{\infty}$ & $\Xi$ & $\widehat{B D}$ & $\widehat{\varrho}$ & $\Xi$ & $\widehat{\infty}$ & $\widehat{S}$ & 용 \\
\hline
\end{tabular}


表 2 〈当科における鼻・副鼻腔乳頭腫10例の症状>

\begin{tabular}{|c|c|c|c|}
\hline 症 & 状 & 例 数 & $(\%)$ \\
\hline 鼻 & 閉 & 8 例 & $(80 \%)$ \\
\hline 頭 & 痛 & 5 例 & $(50 \%)$ \\
\hline 鼻 & 出 & 5 例 & $(50 \%)$ \\
\hline 後 & 漏 & 4 例 & $(40 \%)$ \\
\hline 鼻 & 漏 & 3 例 & $(33 \%)$ \\
\hline 煩 & 部 痛 & 3 例 & $(33 \%)$ \\
\hline & 部 腫 脹 & 1 例 & $(10 \%)$ \\
\hline
\end{tabular}

ことを指摘している．何れにしても，再発まで の期間は数週間から，数年と文献的にもまちま ちであり，長期間の経過観察が必要である.

また，乳頭腫と悪性腫瘍の混在，又は移行に ついて Calcaterra ${ }^{12)} ら の 34$ 例中 3 例 $(9 \%)$, Yamaguchi ${ }^{13)}$ らの15例中 8 例 (53\%), Batsa$\mathrm{kis}^{9)}$ らの337例中 47 例 $(14 \%), \mathrm{Smith}^{14)}$ らの 8 例中 1 例 $(12.5 \%)$, 斎藤 ${ }^{1}$ らの 106 例中 13 例 (12.3\%) と，その頻度は一定しない。ささらに, 悪性像とその予後に関し，粟田口占) らは上皮の 乳頭状増殖の, 基底細胞様の細胞の配列, 異型 性などを予後との関連において重視し，别に， 渡辺 ${ }^{111}$ は, 基底膜の断裂の有無を重要視し，た
とえ核分裂が多く, 細胞の異型性があっても, 基底膜の断裂がなりれば，予後は良いとした。

本症の治療については, 初回治療における腫 瘍の徹底的摘出が基本とされるが，手術方法に ついては，Caldwell-Luc 氏手術，Denker 氏 手術，さらに，悪性腫瘍に準じて上顎全摘術な どの種々の手術法が挙げられるが, 採用すべき 手術す法については，人により意見が異なって いる．自験例では，根治手術不能例（症例 3 , 症例 7 ) を除いては, 特に広範囲手術は施行せ ず，腫瘍の周囲粘膜をやや広範囲に含み摘出す ることで, 徹底的摘出を試み, 現在のところ比 較的良好な予後を得ている. さらに, 手術操作 の一つとして, 凍結手術 (Rothfeld ${ }^{16)}$ ), 電気 烧灼を挙げるものもいる。

放射線治療については, 乳頭腫自体の $\mathrm{X}$ 線感 受性は低いとされるが (渡辺 ${ }^{11)}$, 遠藤 ${ }^{17)}$ ), 特 に長期罹患例では, 試験切除にて, 単に乳頭腫 の所見のみでも，上皮内癌が存在する可能性が ある為，積極的に術後照射をおてなう方が良い とする意見之 (粟田口 ${ }^{18)}$ )，悪性化の疑的机 場合には照射が必要とする意見1)，さらに，周 辺部の徹底的摘除により完治可能であり, 浸㵎

表 3 <当科における鼻・副鼻腔乳頭腫の存在部位>

\begin{tabular}{|c|c|c|c|c|c|c|c|c|c|c|c|c|c|c|}
\hline & & & & \multicolumn{3}{|c|}{ 自 } & \multicolumn{3}{|c|}{ 験例 } & \multirow{2}{*}{ Norris $^{8)}$} & \multirow{2}{*}{\multicolumn{2}{|c|}{ 笹 $木^{2}$}} & \multirow{2}{*}{ 斎 } & \multirow{2}{*}{ 藤11 } \\
\hline & & & & $\hat{o}$ & $(8)$ & 우 & (2) & 計 ( & (10) & & & & & \\
\hline \multicolumn{2}{|c|}{ 鼻 } & \multicolumn{2}{|c|}{ 腔 } & & 6 & & 2 & & 8 & 27 & & 30 & & 62 \\
\hline \multirow{3}{*}{$\begin{array}{l}\text { 副 } \\
\text { 鼻 } \\
\text { 腔 }\end{array}$} & 前 & 頭 & 洞 & & 0 & & 0 & & 0 & 2 & & 0 & & 0 \\
\hline & 篩 & 骨 & 洞 & & 1 & & 0 & & 1 & 4 & & \multirow{2}{*}{14} & \multirow{2}{*}{\multicolumn{2}{|c|}{25}} \\
\hline & 上 & 顎 & 洞 & & 7 & & 0 & & 7 & 7 & & & & \\
\hline
\end{tabular}

表 4 <当科における鼻・副鼻腔乳頭腫10例の病理組織像の経時的変化>

Papilloma (Inverted type)

Papilloma (Inverted type)

Papilloma +
(Inverted type) $\left\{\begin{array}{l}\text { Carcinoma in situ } \rightarrow \text { Recurrence of papilloma }(+) \\ \text { Low grade malignancy } \rightarrow \text { Recurrence }(-)\end{array}\right.$
1 例

6 例

1 例

1 例

1 例 
傾向，破壊傾向を示すすのでなければ，放射線 治療(必要でないとする意見 ${ }^{7)}$ 等, 積極的なも のから，消極的なものまであるが，北条ら゙3は， 過去18年間の鼻 - 副鼻腔乳頭腫症例55例中（う ち，15例に放射線治療施行）記載の明らかな43 例につき検討を加えた結果, 初回, 癌化傾向を 認める10例のうち 5 例（50\%）飞, 術後, 悪性
化を認めるが, 初回より, 組織学的に悪性像を 認めない例では33例中 1 例（3\%）のみが悪化 したに止まり，放射線治療の有無に関らず，悪 性化の恐れは, 極めて少ない, と結論してい る。自験例では，原則として悪性像を呈したも のには，放射線照射を追加し，予後は比較的良 好である。

\section{結語}

(1) 当教室において, 昭和 52 年 4 月より昭和 57 年 6 月の間に, 10 例（男性 8 例, 女性 2 例, 平均 年令 50.2 才）の鼻・副鼻挖乳頭腫症を経験した。

(2) 症状としては鼻閉 (8 例), 頭痛 ( 5 例), 鼻出血 ( 5 例), 後鼻漏 ( 4 例) の順に多く, 副鼻 腔炎に類似するが，主訴に限れば片側性鼻閉，鼻出血が多かった。

(3) 自験例では, 腫瘍の存在部位は, 鼻腔 8 例, 上顎洞 7 例, 箳骨洞 1 例と諸家の報告に比し, 上䫟洞に存在するものが多かった。

(4) 病理組織学的には，10例すべてが inverted popilloma で，うち悪性像は 3 例に認められた.

（5）治療については, 腫瘍の完全摘出を第一選択とし, 悪性像を認めるものには, 放射線療法, および化学療法を追加した.

本論文の要旨は第27回日耳鼻東海地方部会連合会において口演した。

\section{主 要 文 献}

1）斎藤洋三，他：鼻前庭乳頭腫の 1 例と悬中隔乳頭 腫の 1 例一鼻副鼻腔乳頭腫之鼻前庭良性腫煬の統 計的観察一. 耳陮科 $41: 269 \sim 275,1969$.

2 ）笹木実, 他：日本耳鼻咽喉科全書, 第 2 巻, 第 4 冊, 201 210, 金原出版, 1955.

3）北条仁, 他：鼻 - 副鼻腔乳頭症例. 医療 $26: 533$ $\sim 537,1972$.

4) 高田洋美, 他：鼻・副鼻腔乳頭腫の 4 例. 耳喉科 $46: 179 \sim 184,1974$.

5 ）土井伝・我教室最近10ケ年に於ける鼻腔及び副鼻 腔腫煬の統計的観察. 大日耳鼻 $49: 508 \sim 511$, 1943.

6) 久保隆一, 他：鼻副鼻腔乳頭腫について.耳鼻と 臨床 $20 ： 735 \sim 739,1974$.

7）松村祐二郎, 他：鼻・副鼻腔乳頭腫の臨床病理組 織学的検索. 耳鼻之臨床 $16: 270 \sim 280,1970$.

8 ) Norris, H. J. : Papillary lesions of the nasal cavity and paransal sinuses. II : Inverting papillma. A study of 29 cases. Laryngoscope
$73: 1 \sim 17,1963$.

9 ) Batsakis, J. G. : The pathology of head and neck tumors; Nasal cavity and paranasal sinuses, Part 5. Head \& Neck surg, 2/5(410 〜 419), 1980.

10) Snyder, R.N. : Papillomatosis of nasal cavity and paranasal sinuses (inverted papilloma, squamous papilloma) Cancer (Philad) 30 : 668〜690, 1972.

11）渡辺嘉彦：鼻副鼻腔乳頭腫症例. 日耳鼻 73 ： 1789 1795, 1970.

12) Calcaterra, T.C. : Inverting papillomas of the nose and paranasal sinuses. Laryngoscope 90/1, (53 60), 1980.

13) Yamaguchi, K. T. : Inverted papilloma and squamous cell carcinoma. J. Otolaryngol. 8/2, (171 178), 1979.

14) Smith, A.T, et al : Papillary lesions of the nose and sinuses. Ann. Otol. Rhinol. and La- 
ryng $71: 511 \sim 524,1962$.

15）粟田口省吾, 他 : 鼻・副鼻腔の乳嘴腫. 日耳鼻 $67:$ 146 152, 1964 .

16) Rothfeld P. et al : Epithelial (inverted) papilloma : A correlatea radiological-histological study. Clin. Radiol. 28/5, 539 544, 1977.

17）遠藤泰介, 他：鼻腔乳頭腫の 1 症例. 耳鼻 26 :
$563 \sim 567,1980$.

18）栗田口省吾, 他：鼻・副鼻腔の良性腫煌につい て. 耳㬋 $49: 833 \sim 840,1977$.

別刷請求先：干田 均

T470-11 豊明市沓掛町田楽ケ䆶 $1-98$

名古屋保健衛生大学医学部耳鼻咽喉科学教室) 